\title{
MASTER
}

\section{Continuous Environmental Monitoring for Aqueous Effluents}

W. W. Pitt, Jr.

G. Jones, Jr.

OPERATED BY

UNION CARBIDE CORPORATION FOR THE UNITED STATES DEPARTMENT OF ENERGY 


\section{DISCLAIMER}

This report was prepared as an account of work sponsored by an agency of the United States Government. Neither the United States Government nor any agency Thereof, nor any of their employees, makes any warranty, express or implied, or assumes any legal liability or responsibility for the accuracy, completeness, or usefulness of any information, apparatus, product, or process disclosed, or represents that its use would not infringe privately owned rights. Reference herein to any specific commercial product, process, or service by trade name, trademark, manufacturer, or otherwise does not necessarily constitute or imply its endorsement, recommendation, or favoring by the United States Government or any agency thereof. The views and opinions of authors expressed herein do not necessarily state or reflect those of the United States Government or any agency thereof. 


\section{DISCLAIMER}

Portions of this document may be illegible in electronic image products. Images are produced from the best available original document. 


\section{Printed in the United States of America. Available from National Technical Information Service \\ U.S. Department of Commerce \\ 5285 Port Royal Road, Springfield, Virginia 22161}

NTIS price codes-Printed Copy: A03 Microfiche A01

This report was prepared as an account of work sponsored by an agency of the United States Government. Neither the United States Government nor any agency thereof, nor any of their employees, makes any warranty, express or implied, or assumes any legal liability or responsibility for the accuracy, completeness, or usefulness of any information, apparatus, product, or process disclosed, or represents that its use would not infringe privately owned rights. Reference herein to any specific commercial product, process, or service by trade name, trademark, manufacturer, or otherwise, does not necessarily constitute or imply its endorsement, recommendation, or favoring by the United States Government or any agency thereof. The views and opinions of authors expressed herein do not necessarily state or reflect those of the United States Government or any agency thereof. 
Contract No. W-7405-eng-26

CHEMICAL TECHNOLOGY DIVISION

CONTINUOUS ENVIRONMENTAL MONITORING

FOR. AQUEOUS EFFLUENTS

W. W. Pitt, Jr. and G. Jones, Jr.

Date Published: May 1980

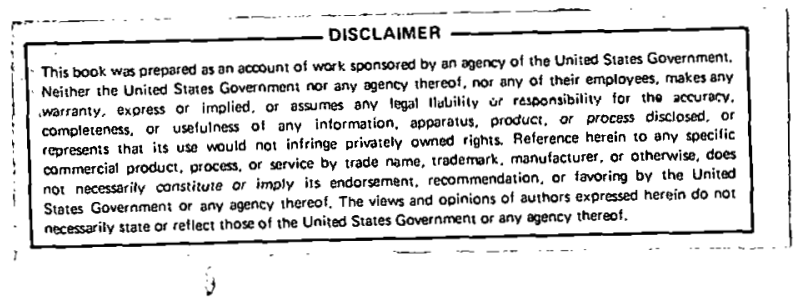

OAK RIDGE NATIONAL LABORATORÝ

Oak Ridge, Tennessee 37830

operated by

UNION CARBIDE CORPORATION

for the

DEPARTMENT OF ENERCY 


\section{THIS PAGE}

\section{WAS INTENTIONALLY \\ LEFT BLANK}




\section{CONTENTS}

Page

ABSTRACT . . . . . . . . . . . . . . . . . . . . . . 1

1. INTRODUCTION . . . . . . . . . . . . . . . . . . . . . 1

2. INSTRUMENT DESCRIPTION . . . . . . . . . . . . . . . . 2

2.1 Continuous Chemical Oxygen Demand Monitor . . . . . . . 4

2.2 Polynuclear Aromatic Hydrocarbon Monitor. . . . . . . . 11

2.3 Auxiliary Components. . . . . . . . . . . . . 13

3. APPLICATIONS AND RESULTS . . . . . . . . . . . . . . 14

3.1 Coal Conversion Process Wastewaters . . . . . . . . . 14

3.2 Effluent from Municipal Activated Sludge

Treatment Plant . . . . . . . . . . . . . . 17

3.3 Other Applications. . . . . . . . . . . . . 18

4. SUMMARY. . . . . . . . . . . . . . . . . . . 19

5. REFERENCES . . . . . . . . . . . . . . . . . . . . . 19 


\title{
CONTINUOUS ENVIRONMENTAL MONITORING \\ FOR AQUEOUS EFELUENTS
}

W. W. Pitt, Jr. and G. Jones, Jr.

\begin{abstract}
An aquatic environmental monitor has been developed that will continuously monitor aqueous waste streams from coal processing plants. The monitor contains three different instruments: a continuous chemical oxygen demand monitor and two continuous-flow fluorometers with different excitation-emission characteristics. A prototype instrument was fabricated and evaluated for several different applications. The details of the instrument design and results of its evaluation are presented in this report.
\end{abstract}

1. INTRQDUCTION

The development of continuous monitoring systems for sensitive onsite monitoring of dissolved aquatic pollutants constitutes a very practical, necessary approach to one facet of our growing concern for the perturbation in our environment caused by various anthropogenic energy suurces. The antlcipated increase in the utilization of coal to solve the nation's energy problems makts it clear that to avoid significant damage to our aquatic environment we must be capable of detecting environmentally hazardous compounds being discharged from coal handing and processing plants into receiving waters. Earlier studies have indicated that phenolic compounds and polynuclear aromatic hydrocarbons (PAHs) are two of the most environmentally significant classes of organic constituents likely to be released by coal conversion plants to the receiving waters and requiring monitoring.

This report describes the development of one such monitoring system through the design, fabrication, and evaluation of 'a prototype instrument. The system is a combination of two different instruments: (1) a continuous chemical oxygen demand (CCOD) monitor, which is particularly sensitive to phenolic compounds; and (2) a continuous-flow fluorometer with a wide dynamic range for monitoring dissolved PAHs. The CCOD and two of the flow fluorometers, with different excitation-emission characteristics, 
were incorporated into a single system for continuous monitoring of waste streams from coal processing plants; the combined instrument is called an aquatic environmental monitor (AEM).

\section{INSTRUMENT DESCRIPTION}

The AEM is designed to accept either a small, continuous sidestream of a single effluent or a sequence of injected samples from several aqueous effluents; it will measure two characteristics of the aqueous samples in series: chemical oxygen demand (COD) and ultraviolet (uv) fluorescence. The instrument contains three continuous flow monitors, a continuous COD monitor, and two flow fluorometers (Fig. 1), with the response from each displayed on a strip chart. Provisions are made to allow periodic rezeroing and calibration of each monitor. A photograph of the prototype instrument is shown in Fig. 2.

ORNL OWG $76 \cdot 17432$ A 2

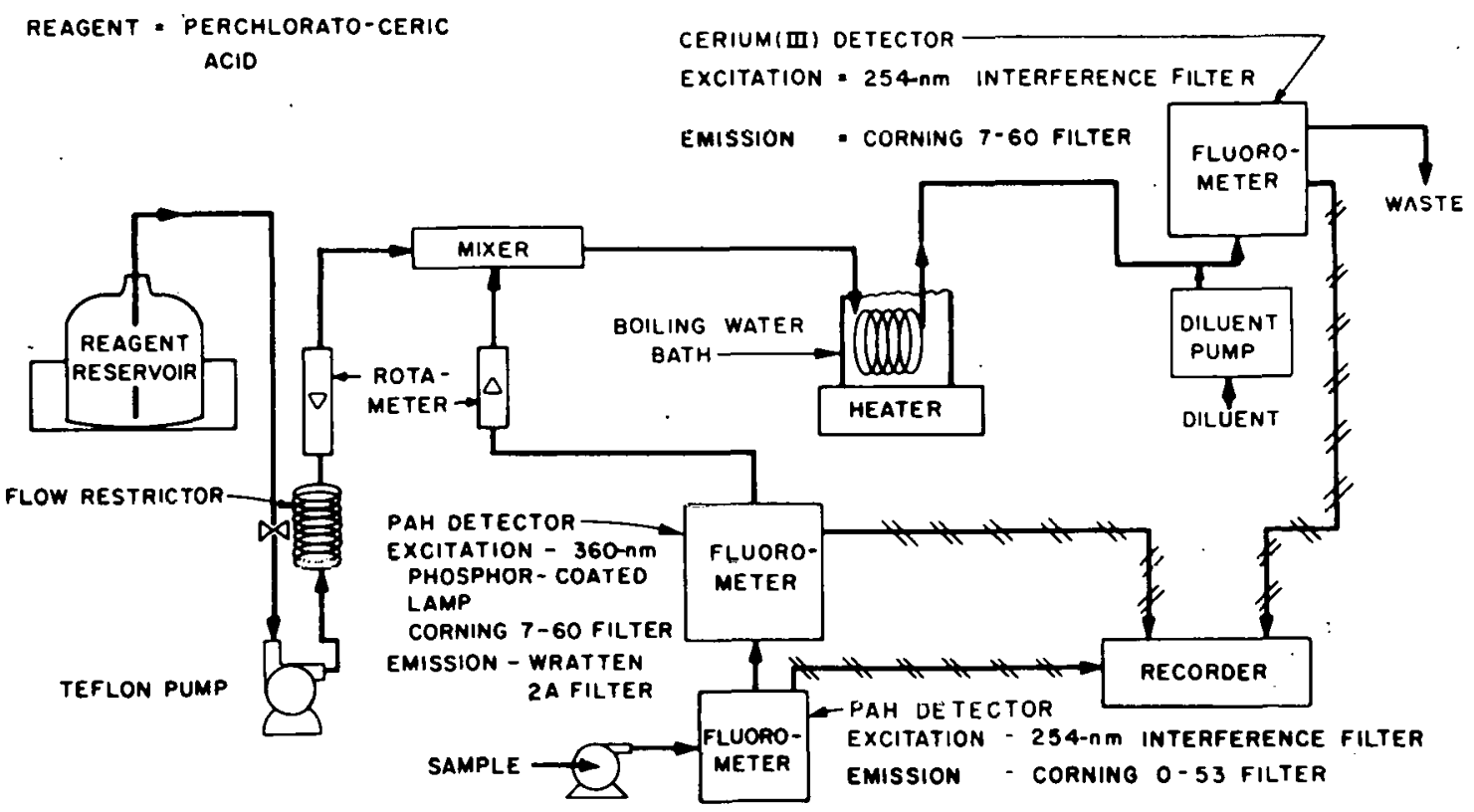

Figure 1. Schematic of aquatic environmental monitor. 


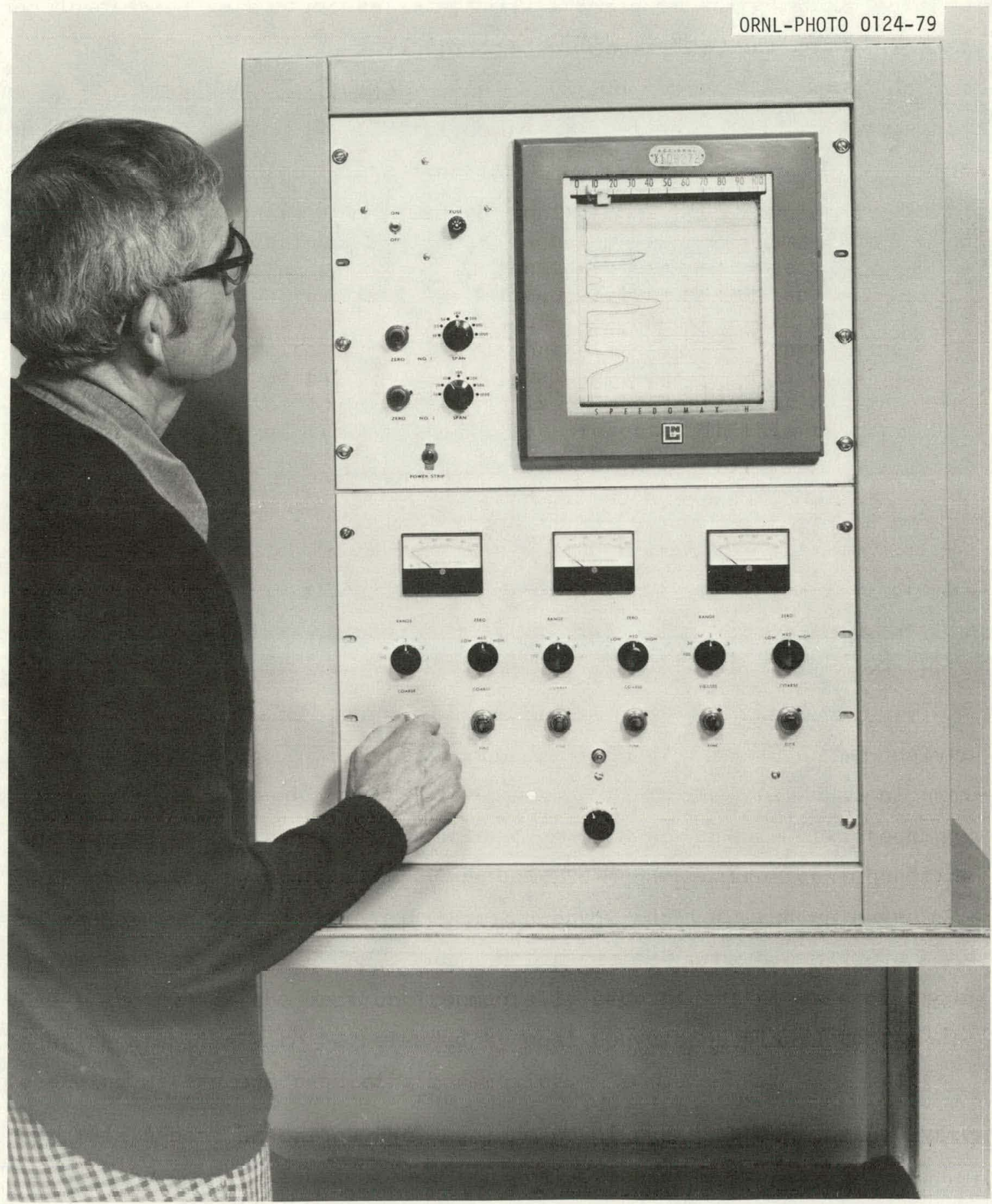

Figure 2. Photograph of aquatic environmental monitor. 


\subsection{Continuous Chemical Oxygen Demand Monitor}

The CCOD monitor is based on cerate oxidimetry using perchloratoccric acid; that is, the measurement of the fluorescent cerium(III) resulting from the reduction of cerium(IV) by any oxidizable compound in the stream being monitored. Concentrations of cerium(III) from $10^{-8}$ to $10^{-4} \underline{\mathrm{M}}$ can be readily determined fluorometrically by exciting with uv light (254 nm) and measuring the light emission at $350 \mathrm{~nm},{ }^{1}$ thereby measuring the COD of waters at levels as 1 ow as $100 \mu \mathrm{g} / \mathrm{l}$. The CCOD monitor that was incorporated in the aquatic environmental monitor was a slightly modified version of one described previously. ${ }^{2}$

The key component of the system is the flow fluorometer, which has been described in detail elsewhere ${ }^{3}$ but is also briefly described here. The flow fluorometer, shown schematically in Fig. 3, consists of a fluorometer body, electronics chassis, and a high-voltage power supply. The fluorometer body (Fig. 4) is a machined aluminum block that contains a low-pressure mercury lamp, a 254-nm interference primary filter, a quartz-tube flow cell, two Corning 7-60 secondary filters, a photomultiplier tube and housing, and a photoconductor for compensation of changes in lamp intensity. In this situation, nature was exceptionally benevolent, because the excitation maximum for trivalent cerium is very close to the most intense emission line of the low-pressure lamp, $253.7 \mathrm{~nm}$; the emission spectrum of cerium(III) corresponds almost precisely with the pass-band of the Corning 7-60 filters. These characteristics, plus the S-11 photo response characteristics of the photomultiplier, provided an exceedingly low background due to reflected light and allowed the construction of a very sensitive instrument from relatively inexpensive components.

The calibration curve for the flow fluorometer with $\mathrm{Ce}^{3+}$ solutions io ohown in Fig. 5. Under the normal reaction conditions, it was determined that a stoichiometric reagent-to-sample ratio of 2.5 is required for maximal oxidation (see Fig. 6). Since the electrochemical stoichiometry for the complete oxidation of phenol to $\mathrm{CO}_{2}$ requires 28 mol of $\mathrm{Ce}^{4+}$ per mol of phenol, the ratio of 2.5 shown in Fig. 6 is above normal stoichiometric ratio. This is dramatically illustrated in Fig. 7 where maximal response to phenol concentrations ranging from 1.1 to $10^{-5}$ 
ORNL DWG. NO. $72-4 \geq 13$

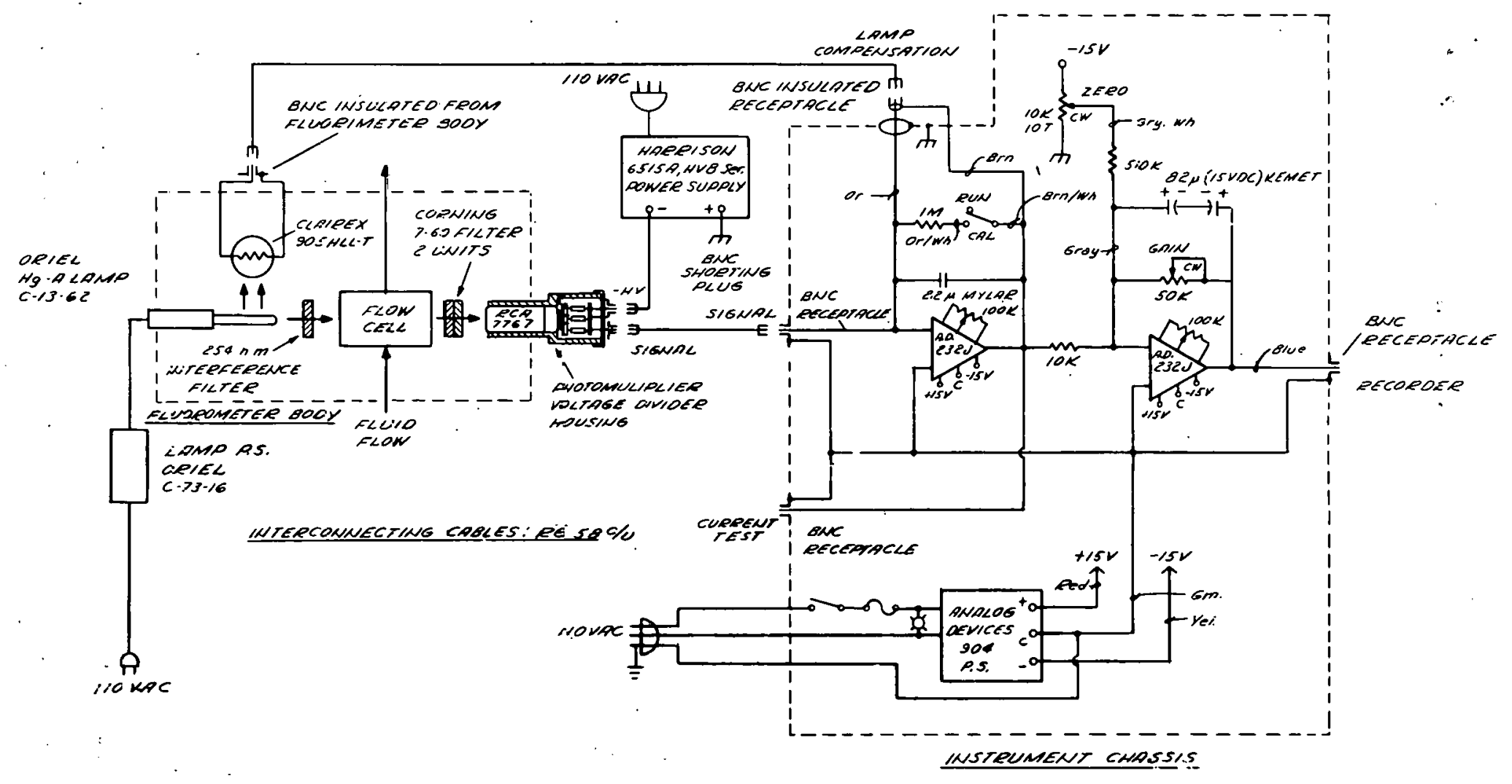

Eigure 3. Schematic of flow fluorometer. 


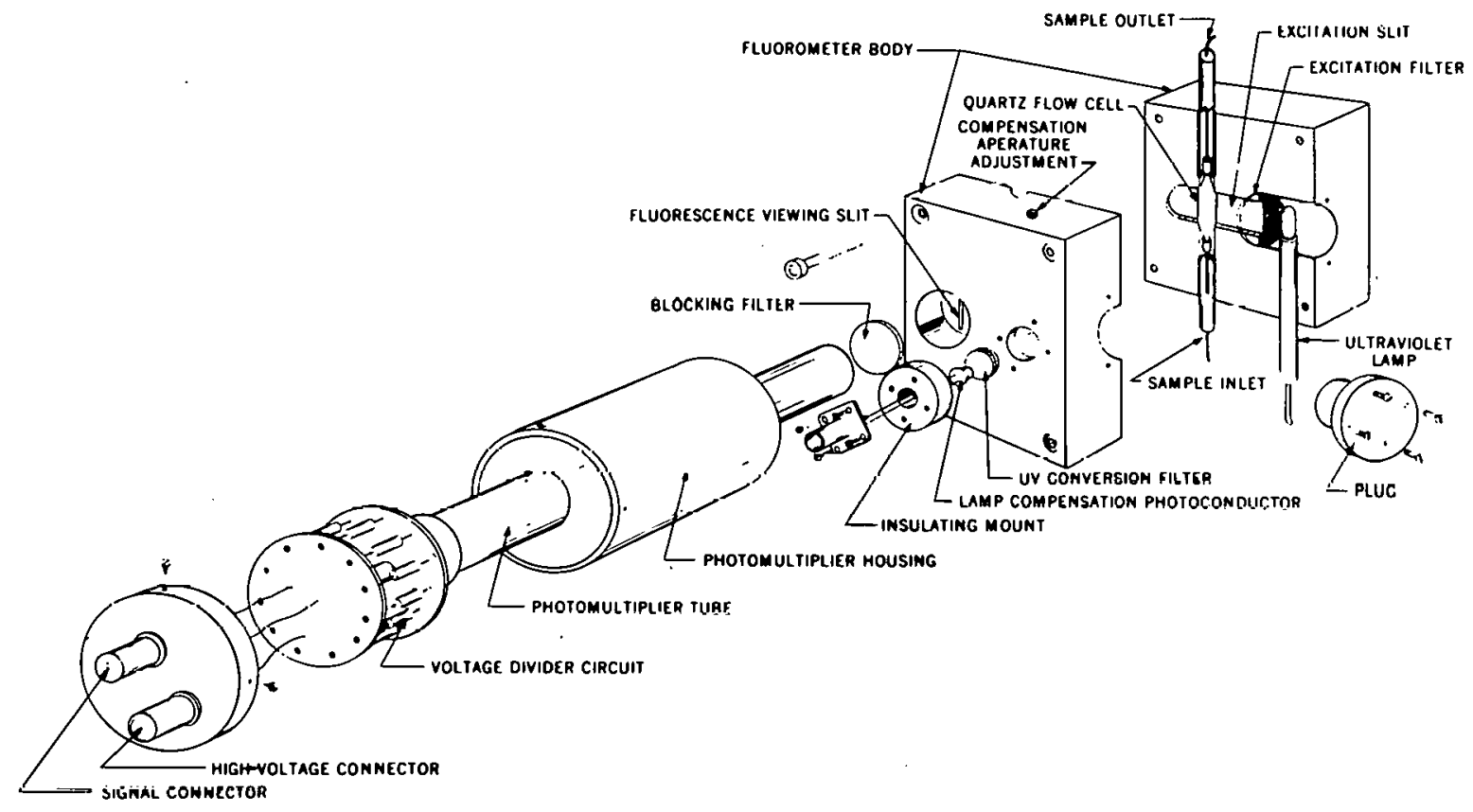

Figure 4. Exploded isometric view of flow fluorometer body.

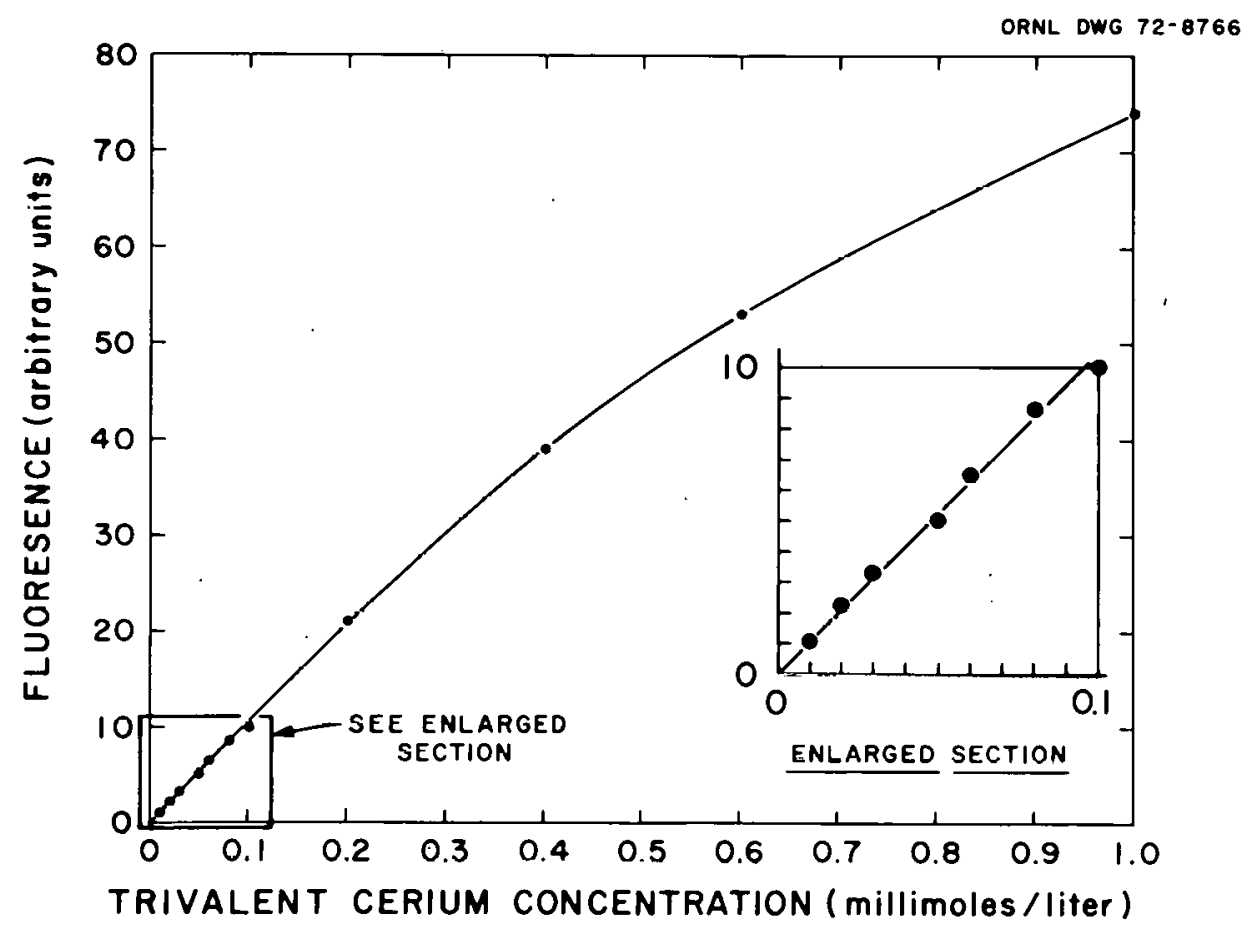

Figure 5. Calibration curve for ORNL flow fluorometer. 


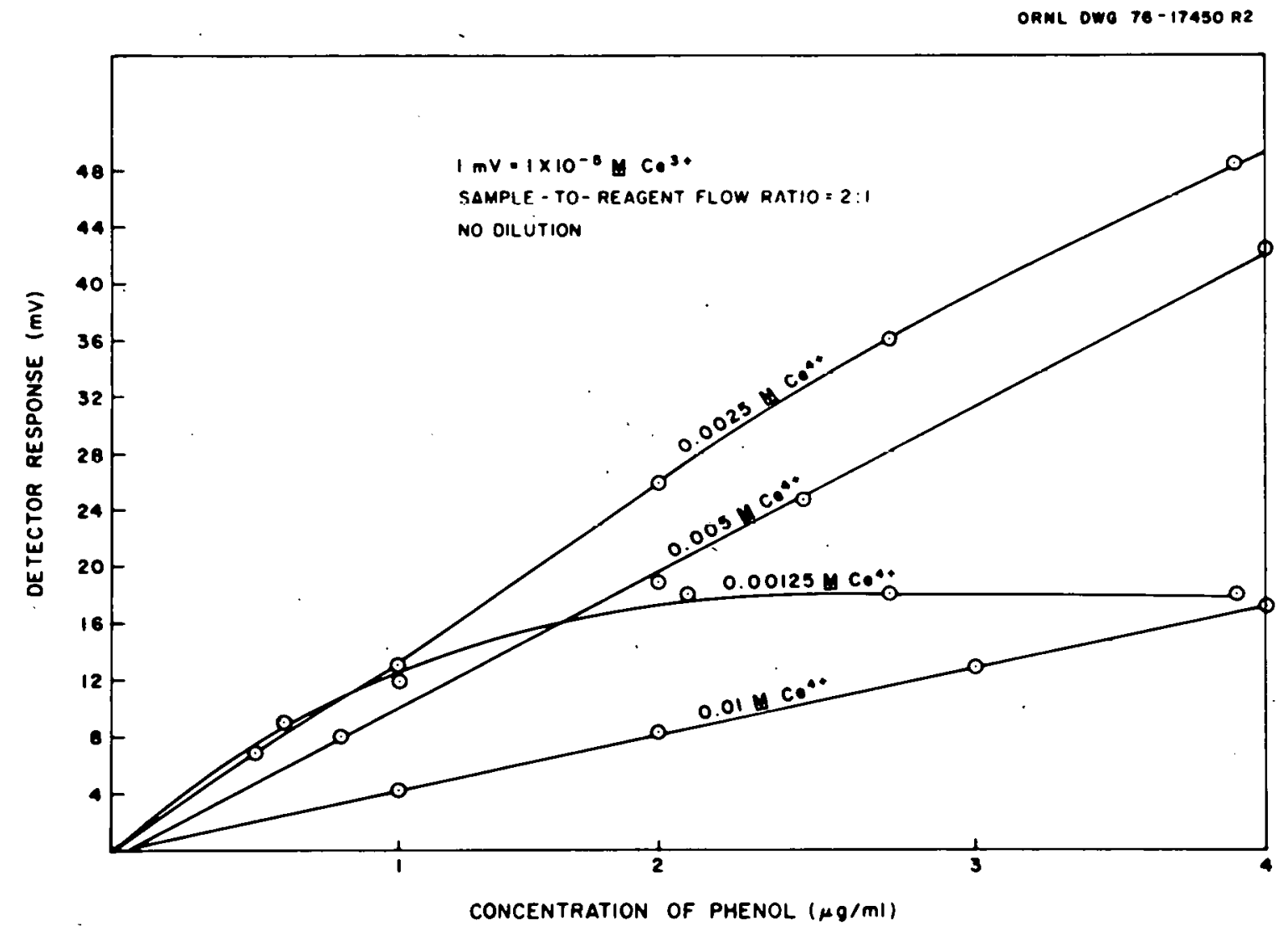

Figure 6. Effect of reagent-to-sample stoichiometric ratio on the response of the continuous chemical oxygen demand monitor.

ORNL DWG 79-1435

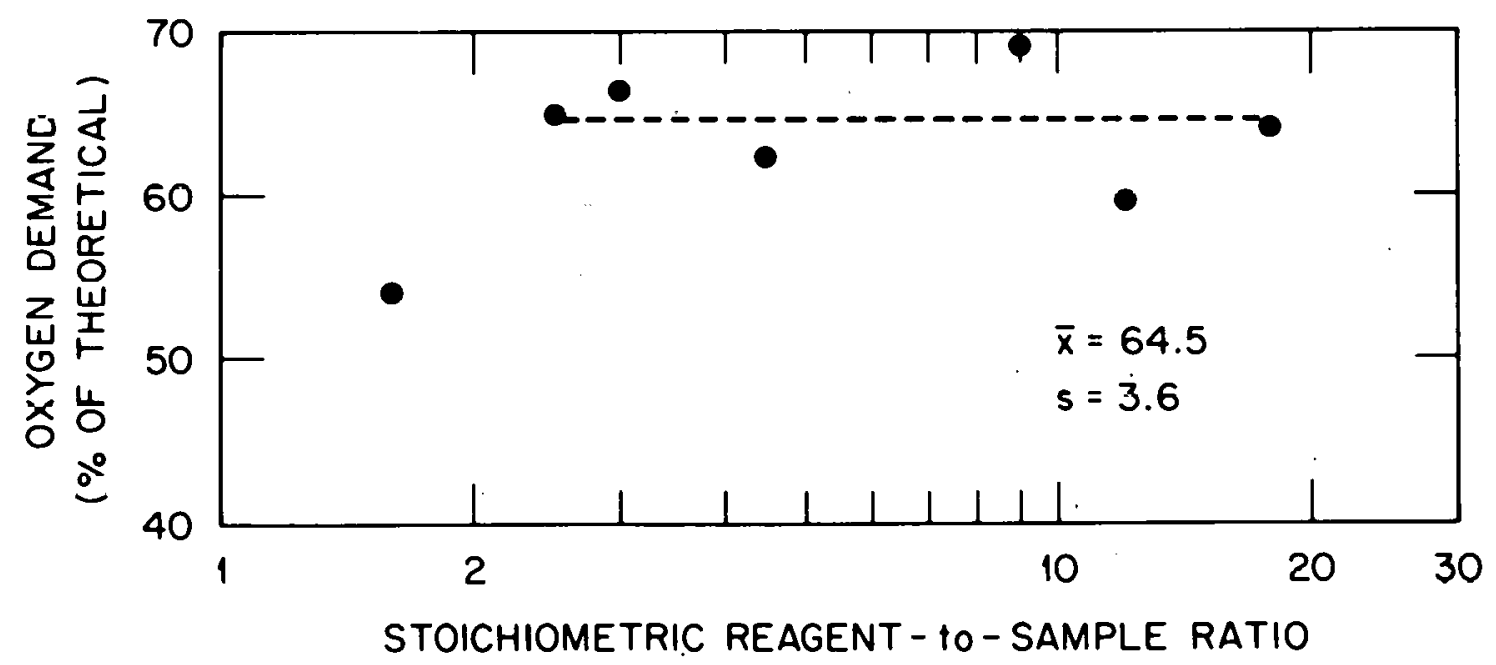

Figure 7. Effect of reagent concentration on the response of the continuous chemical oxygen demand monttor. 
to $4.4 \times 10^{-5} \underline{\mathrm{M}}$ is shown for a $\mathrm{Ce}^{4+}$ concentration of $2.5 \times 10^{-3} \mathrm{M}$; in this case, the reagent-to-sample ratio ranges from 8 to 2 . A dramatic falloff in response is shown for the same range of phenol concentration using $1.25 \times 10^{-3} \underline{\mathrm{M} \mathrm{Ce}}{ }^{3+}$. The amount of reagent is adequate for phenol at $1 \mathrm{\mu g} / \mathrm{ml}$; however, at higher concentrations of phenol, the reagent-tosample ratio is definitely suboptimal. Conversely, Fig. 7 also shows the quenching effect of $\mathrm{Ce}^{4+}$ on the fluorescence of $\mathrm{Ce}^{3+}$ where higher concentrations of the reagent were used.

Maximal response can be assured by using higher reagent-to-sample ratios for the oxidation but diluting the mixture prior to 1ts entrance into the fluorometer. The reagent concentration and the ratio of reagent to sample thus are chosen so that no more than $40 \%$ of the cerfum (IV) will be utilized. The mixture is then diluted with ultrapure water to a final cerium (III, IV) concentration of $2 \mathrm{mM}$ or less to reduce selfquenching during measurement of the fluorescent trivalent cerium in the flow fluorometer.

Various combinations of reagent concentrations and sample, reagent, and diluent flow rates were utilized to measure the COD of sample streams containing 1 to $40 \mathrm{mg}$ of phenol per liter. It was determined that sufficient sensitivity and adequate linear range could be obtained as long as the following constraints were met:

1. $<2 \mathrm{mM} \mathrm{Ce}$ in the fluorometer, and

2. a stoichiometric reagent-to-sample ratio $>3$.

To meet these constraints: the following operating conditions were chosen for the aquatic environmental monitor:

\begin{tabular}{|c|c|c|}
\hline Stream & Flow rate $(\mathrm{ml} / \mathrm{h})$ & Concentration \\
\hline Sample & 10 & 1 to $30 \mathrm{mg} \cdot \mathrm{COD} / \mathrm{l}^{*}$ \\
\hline Reagent & 5 & $0.02 \underline{\mathrm{M}} \mathrm{Ce}(\mathrm{IV})$ \\
\hline Diluent & 35 & \\
\hline Total & 50 & $2 \mathrm{mM} \mathrm{Ce}$ \\
\hline
\end{tabular}

*By changing the relative flow rates of sample and diluent streams, COD concentrations outside this range can be measured. 
The CCOD was tested in the discrete sample mode by injecting three or more samples of nine organic compounds (representing different classes) dissolved in triply distilled water and three polluted waters with a blark of triply distilled water between each sample. Periodically, a callbration standard containing a known amount of trivalent cerium in distilled water was injected. Quantities of each organic compound to produce about 10-mg theoretical COD per liter were dissolved in distilled water. At approximately 5-min intervals, the sample tube was placed into one of these solutions and a l-min sample was withdrawn. During the remainder of the cycle the sample tube was inserted into distilled water. The COD of the sample was indicated by the height of a peak on the strip-chart recorder $10 \mathrm{~min}$ after the sample was withdrawn. The system was calibrated periodically with three l-min samples of a cerium(III) solution of known concentration ( $1 \times 10^{-3}$ to $2 \times 10^{-3} \underline{\mathrm{M}}$ or 8 - to $16-\mathrm{mg} / \mathrm{l}$ oxygen demand). An example of the recorder trace is shown in Fig. 8, and the results of several series of runs using the selected organic compounds and pollution samples are shown in Table 1.

The CCOD monitor was also evaluated using solutions containing known concentrations of phenol. Shown in Fig. 9 is the detector response

QRNI. DWG 7P - RTRR

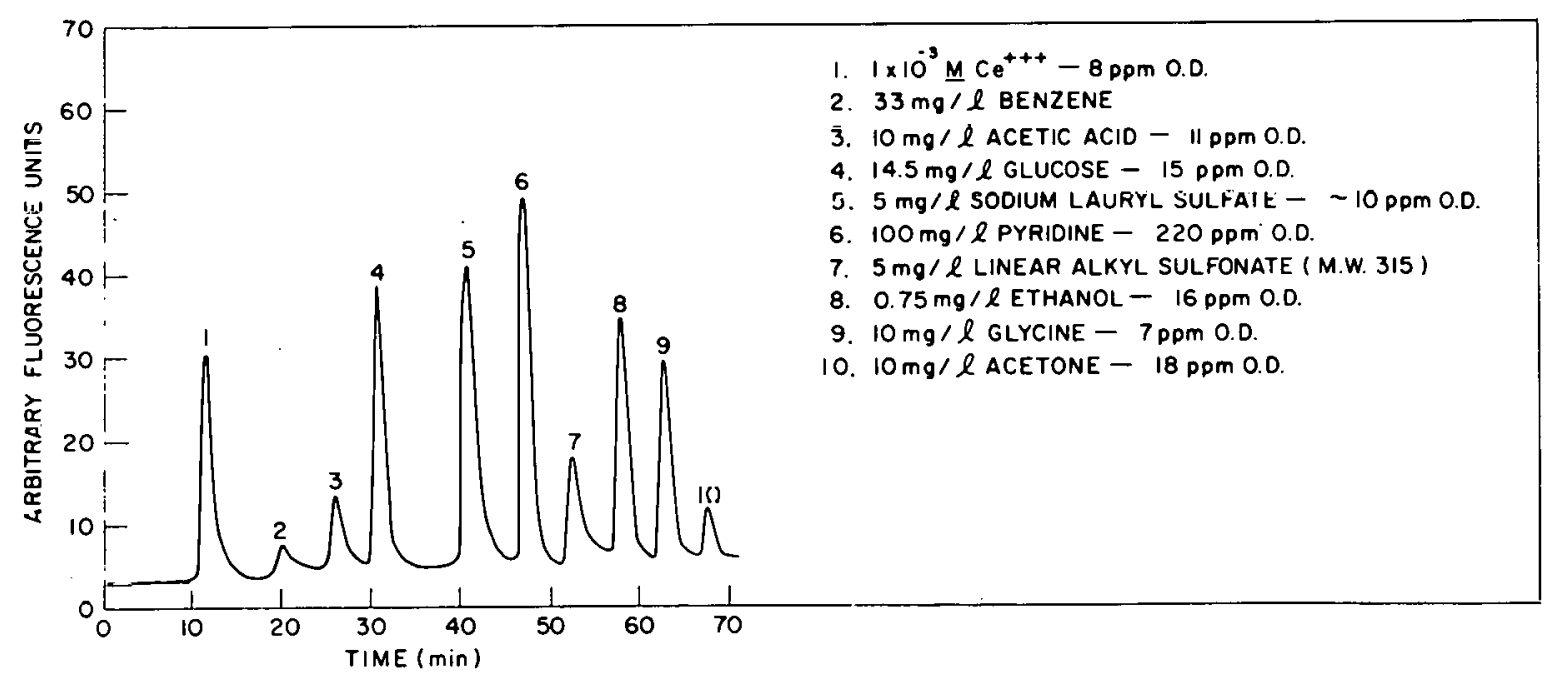

Figure 8. Example of recorder trace from continuous chemical oxygen demand monitor when used a a discrete sample analyzer. 
Table 1. Oxidation of organic compounds and polluted waters by perchloratoceric acid COD method

\begin{tabular}{|c|c|c|c|c|c|}
\hline \multirow[b]{2}{*}{ Sample } & \multirow{2}{*}{$\begin{array}{l}\text { Concentration } \\
(\mathrm{mg} / \mathrm{l})\end{array}$} & \multirow{2}{*}{$\begin{array}{l}\text { Number of } \\
\text { determinations }\end{array}$} & \multicolumn{2}{|c|}{$\begin{array}{l}\text { Oxygen consumed } \\
(\mathrm{mg} / \mathrm{l})\end{array}$} & \multirow{2}{*}{$\begin{array}{l}\text { Percent of } \\
\text { theoretical } \\
\text { COD }\end{array}$} \\
\hline & & & Average & Range & \\
\hline Acetic acid & 10 & 4 & 6.1 & $5.2-7.4$ & 57 \\
\hline Acetone & 8 & 5 & 3.2 & $3.0-3.3$ & 18 \\
\hline Benzene & 3.3 & 4 & 2.8 & $2.4-3.5$ & 26 \\
\hline Ethanol & 7.5 & 3 & 11.0 & $10.8-11.1$ & 69 \\
\hline Glucose & 14.5 & 4 & 17.4 & $15.9-17.9$ & 112 \\
\hline Glycine & 10 & 4 & 3.0 & $2.8-3.2$ & 46 \\
\hline Linear alkyl sulfonate & 5 & 5 & 6.9 & $6.3-7.4$ & 105 \\
\hline Pyridine & 10 & 6 & 3.5 & $3.2-3.6$ & 16 \\
\hline Sodium lauryl sulfate & 5 & 5 & 13.5 & $12.8-14.6$ & 135 \\
\hline $\begin{array}{l}\text { Sewage plant effluent } \\
\quad \text { (industrial plant), COD }\end{array}$ & 19 & 5 & 16.5 & $14.8-18.1$ & \\
\hline $\begin{array}{l}\text { Secondary sewage plant } \\
\text { effluent (Oak Ridge, } \\
\text { Tenn.), BOD } \\
\end{array}$ & 6 & 5 & 25.9 & $24.2-27.4$ & \\
\hline Clinch River water, COD & 8 & 3 & 7.8 & $7.5-8.0$ & \\
\hline
\end{tabular}




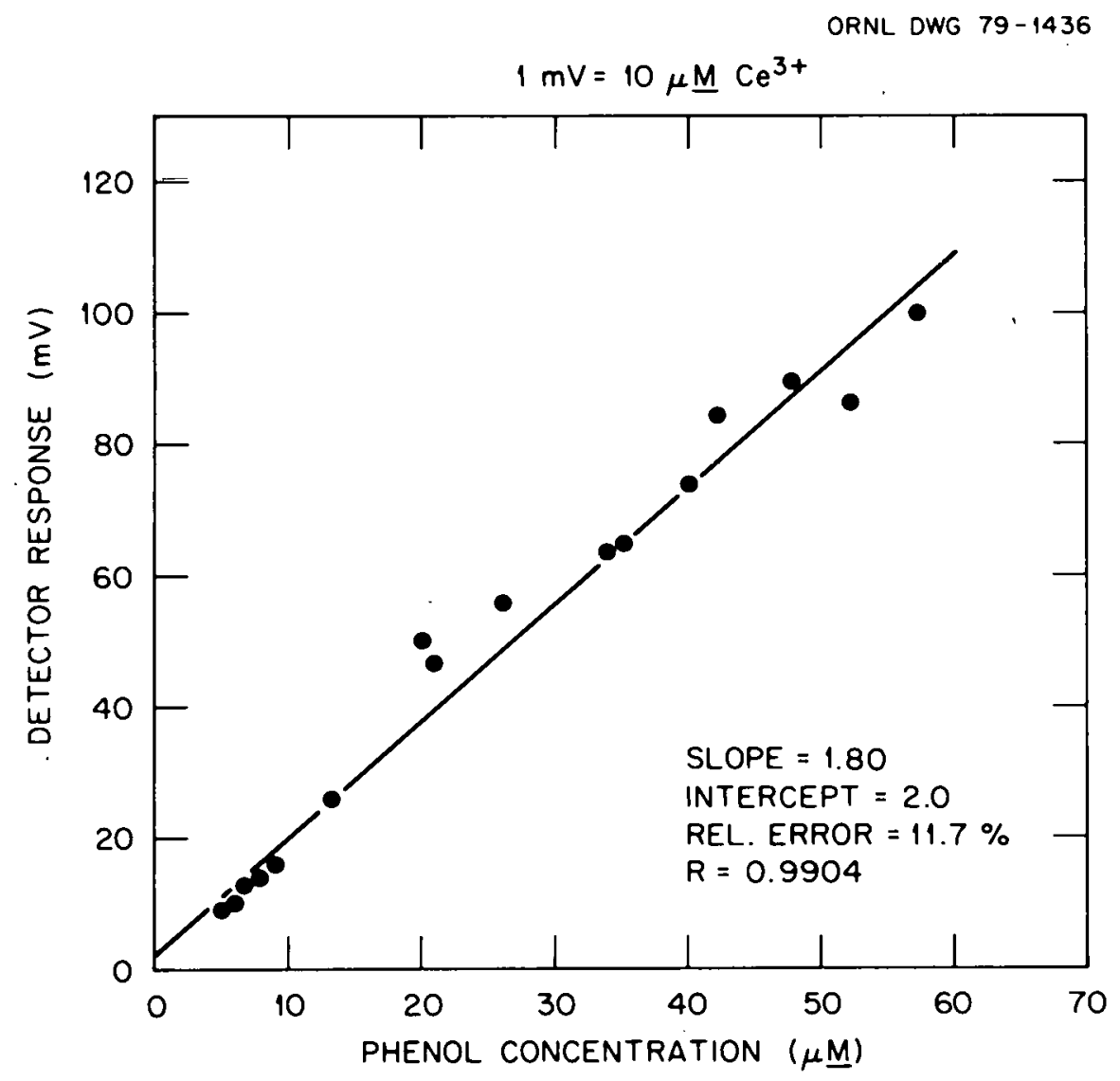
monitor.

Figure 9. Calibration curve for continuous chemical oxygen demand (fluorometer adjusted to provide $1-\mathrm{mV}$ output with $10 \mu \underline{\mathrm{M}} \mathrm{Ce}^{3+}$ in the flow cell) as a function of the concentration of phenol in the flow cell.

\subsection{Polynuclear Aromatic Hydrocarbon Monitor}

Since most polynuclear aromatic hydrocarbons (PAHs) are strongly fluorescent when excited by uv 11ght, two inexpensive, continuous-flow fluorometers were incorporated into the AEM to measure contamination by PAIls. Three Lypes of fluorometers were used: (1) a commercial rightangle filter fluorometer (AMINCO Fluorn-Mnnttor, American Inetrument Company, Silver Spring, Maryland); (2) a right-angle filter fluorometer, similar to the one described in Sect. 2.1, but with a different secondary filter; and (3) a bifurcated fiber-optics fluorometer, also designed and fabricated at ORNL. All three used a low-pressure mercury lamp as an 
excitation source, either with a 254-nm interference filter or coated with phosphor emitting light at $360 \mathrm{~nm}$. A Corning 0-53 filter was used as a secondary filter with the 254-mn excitation source, and a Wratten $2 \mathrm{~A}$ filter was used with the 360-nm source. Since the performance of the two right-angle fluorometers was very comparable, they were used interchangeably. (The performance of the bifurcated fiber-optic fluorometer was disappointing; it was considerably less sensitive than the rightangle fluorometers without the expected increase in linear dynamic range.) A calibration curve for the commercial fluorometer ( $\lambda_{\text {ex }}=254 \mathrm{~nm}$ ) using 2,3-benzofluorene as a PAH standard is shown in Fig. 10. The instrument has a measurable response to as little as $0.1 \mu \mathrm{g} / \mathrm{l}$ and a Inear signal output from about 2 to $2000 \mu \mathrm{g} / \mathrm{l}$.

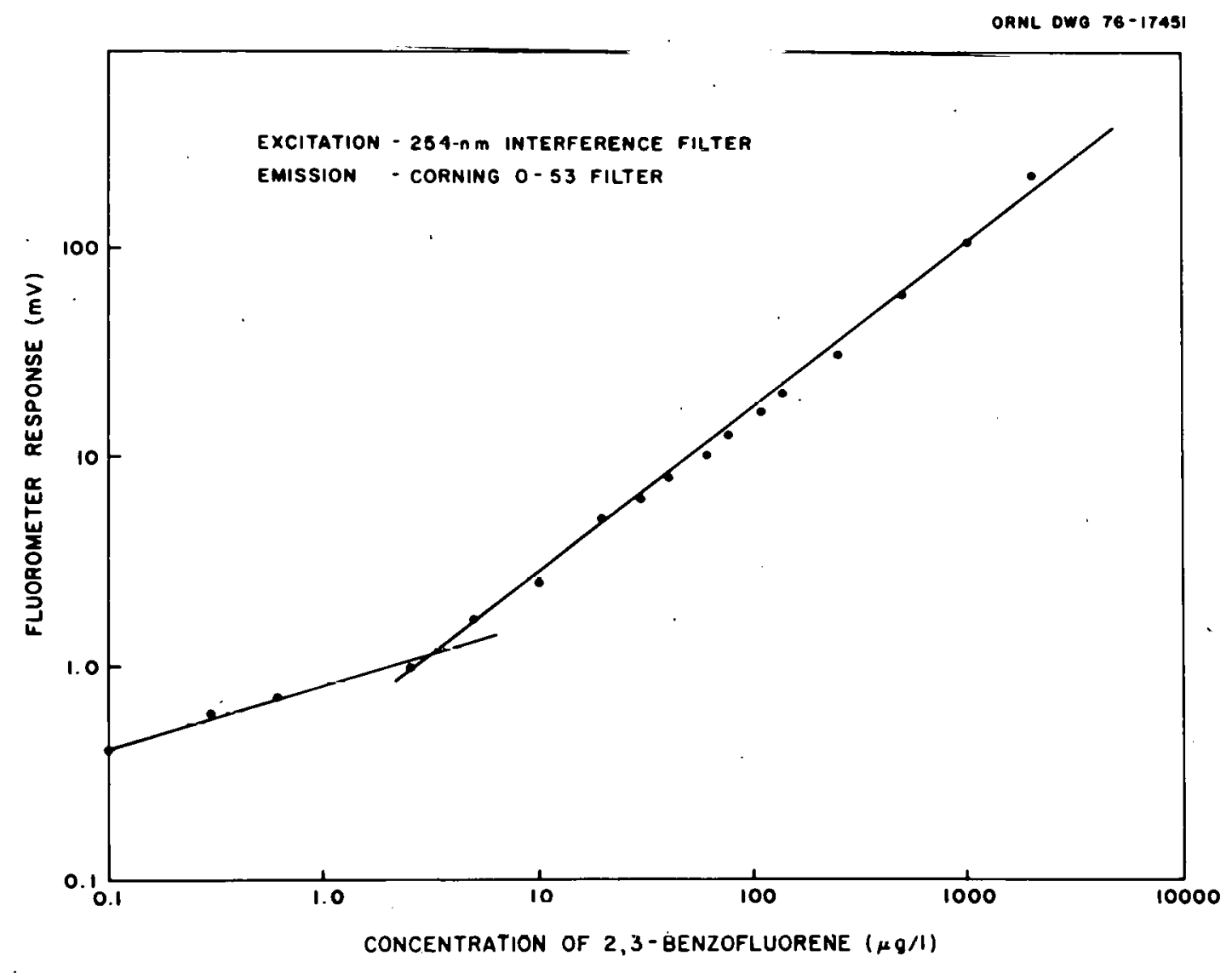

Figure 10. Calibration curve for commercial flow fluorometer. 


\subsection{Auxiliary Components}

The prototype instrument incorporated several auxiliary components to minimize the need for external services, which are $110 \mathrm{~V}$ ac, and occasional filling of reagent reservoirs and emptying of the waste container.

\subsubsection{Fluid-flow systems}

Three controlled, steady flows are required: sample, reagent, and diluent. Sample flows were maintained at a given constant flow rate (10 to $20 \mathrm{ml} / \mathrm{h}$ ) using an SP-1000 Saturn Teflon pump with a throttle valve (Fluorocarbon Co., Anaheim, California). Cerate reagent flow was maintained at a constant flow rate between 5 and $10 \mathrm{ml} / \mathrm{h}$ using a smaller SP-100 Saturn Teflon pump. Controlled diluent (tapwater) flow of between 20 to $60 \mathrm{ml} / \mathrm{h}$ was obtained by gravity flow through a length of small plastic tubing. All flows were measured continuously with small, precisionbore Flowrators (Fischer \& Porter Co., Warmister, Pennsylvania) having sapphire ball floats.

\section{3 .2 Reactor}

The heated reactor was simply a coil of Teflon tubing submerged in a 1000-ml round-bottom flask filled with water maintained at boiling with a Variac controlled heating mantle. Evaporation of water was minimized by use of an air condenser on top of the flask. The length of the reactor tubing was chosen so that the residence time of the mixture was about $10 \mathrm{~min}$.

\subsubsection{Mixers}

Two fluid-stream mixers were used: one to mix the sample and reagent, the other to add diluent to the reaction mixture. To minimize the time for analysis, minimum volume mixers were required. These were made by blowing a small ( $5 \mathrm{~mm} \mathrm{diam),} \mathrm{disc-shapcd} \mathrm{chamber} \mathrm{in} \mathrm{the} \mathrm{center} \mathrm{of} \mathrm{an}$ 210-cm length of 2-mm-I.D. glass tubing and joining a $5-\mathrm{cm}$ length of the same size tubing perpendicular to this chamber. A 3-mm length of nickel wire sealed in glass was used as the stirring bar. These mixers were mounted as inverted " $T$ "s on a small magnetic stirrer, using the two 
horizontal legs as inlets and the vertical leg as the outlet. The connecting Teflon tube, was inserted inside the glass tubing (snug fit) to the mixing chamber, and sealed with heat-shrinkable tubing.

\section{3 .4 Reagent}

The $0.02 \mathrm{~N}$ perchloratoceric acid reagent was prepared by diluting perchloratoceric acid ( $0.5 \underline{\mathrm{N}}$ cerium(IV) in $6 \underline{\mathrm{N}}$ perchloric acid) with $6 \underline{\mathrm{N}}$ perchloric acid. The water used for dilution must be organic free to minimize background fluorescence. Two liters of the reagent were prepared at a time and charged to the reagent reservoir (a 2-l. Tefion bottle). This is sufficient to last for 1 week of continuous operation.

\section{APPLICATIONS AND RESULTS}

The A.EM has been used to monitor the effectiveness of biological treatment in removing phenolics and PAHs from both synthetic waste and authentic coal hydrocarbonization wastewater. It was also used to compare the reduction of $\mathrm{COD}$ and fluorescence by activated sludge treatment of municipal wastewaters. The individual instruments in the AEM have also been used singly--the CCOD to monitor COD from an experimental anaerobic sewage treatment plant, and the PAH monitor to measure possible PAH contamination in drinking water. There are many other possible applications of the AEM and its associated instruments.

\subsection{Coal Conversion Process Wastewaters}

The AEM was primarily designed for monitoring the organic contaminants in the aqueous effluents from cual gasification and liquefaction processes. It has been established that the major classes of contaminants present in wastewater streams irom different coal conversion facilities are phenolics, inorganic ions including trace elements, and PAHs. Table 2 shows the typical values found in untreated wastewater and the anticipated effluent regulations. Although many potential organic contaminants (particularly PAHs) are strongly fluorescent, most are only very sparingly soluble in water and their fluorescence intensity varies considerably. Thus, a qualitative study of the relative solubilities and fluorescences 
Table 2. Pollutants in untreated wastewaters from CCP and anticipated regulations

\begin{tabular}{ccc}
\hline Pollutant & $\begin{array}{c}\text { Wastewater } \\
\text { concentration } \\
(\mathrm{mg} / \mathrm{l})\end{array}$ & $\begin{array}{c}\text { Anticipated } \\
\text { regulations } \\
(\mathrm{mg} / \mathrm{l})\end{array}$ \\
\hline Phenols & $3,000-10,000$ & $0.03-0.3$ \\
$\mathrm{NH}_{3}$ & $1,000-7,000$ & $0.8-5$ \\
$\mathrm{NO}_{3}$ & $3,000-12,000$ & $1-10$ \\
$\mathrm{COD}$ & $3,000-20,000$ & $20-350$ \\
$\mathrm{PAH}$ & 210 & $<0.05$ \\
\hline \multicolumn{2}{c}{$a_{\text {Data taken from ref: 4 in this report. }}$}
\end{tabular}

of several PAHs was made in the following manner. Each compound was initially dissolved in methanol, and this solution was diluted (beginning with a twofold dilution) with distilled water until no precipitation occurred. The fluorescences of the resulting solutions were measured with a fluorometer using 254-nm excitation and a 0-53 corning filter as the secondary filter (see Table 3 ).

It is apparent that the wastewaters generated in coal conversion processes (CCP) must be treated before release to the environment, and the AFM can be used to measure the effectiveness of the treatment for COD, phenols, and PAHs. One proposed method for CCP wastewater treatment is biological oxidation in a fluidized-bed bioreactor. ${ }^{5}$ A prototype AEM was installed in Building 2528 at Oak Ridge National Laboratory (ORNL) to continuously monitor clarified effluent from a bioreactor used to treat synthetic CCP wastewaters, as well as authentic wastewater from a coal hydrocarbonization process. Shown in Fig. 11 are three sections of the AEM recorder chart, indicating its response to different bioreactor changes. Trace A shows the startup transient of the bioreactor, which indicates that after about $12 \mathrm{~h}$ (needed for accumulation of biomass) the effluent from the bioreactor is essentially free of phenolics and PAIIs. Trace $B$ shows the transient associated with replacement of a large fraction of the active biomass with clean solid support. As would be expected, the effectiveness of the bloreactor is reduced, but it quickly 
Table 3. Qualitative solubilities and relative fluorescence of polycyclic aromatic hydrocarbons

\begin{tabular}{|c|c|c|c|}
\hline Compound & $\begin{array}{l}\text { Initial } \\
\text { methanol } \\
\text { solution } \\
(\mathrm{mg} / \mathrm{l})\end{array}$ & $\begin{array}{l}\text { Solubility } \\
\text { in water } \\
\text { using methanol } \\
\text { as carrier } \\
(\mathrm{mg} / \ell)\end{array}$ & $\begin{array}{c}\text { Relative } \\
\text { fluorescence } \\
(\lambda \text { ex, } 254 \mathrm{~nm}, \\
\left.\lambda_{\text {em }} 320 \mathrm{~nm}\right)\end{array}$ \\
\hline Pyrene & 500 & 5 & 1.0 \\
\hline Phenanthrene & 500 & 5 & 0.6 \\
\hline 3,4-Dime thy lphenol & 200 & 100 & $0.05^{c}$ \\
\hline Naphthalene & 500 & 250 & $0.22^{c}$ \\
\hline 2,3-Dimethylnaph thalene & 1000 & 10 & 0.70 \\
\hline 2-Methylnaphthalene & 1000 & 500 & $0.50^{c}$ \\
\hline Adamantane & 200 & 0 & \\
\hline 2,3-Benzofluorene & 100 & 50 & 2.8 \\
\hline Triphenylene & 500 & 15 & 0.008 \\
\hline Retene & 320 & 10 & 0.05 \\
\hline 2,3-Benzindene & 900 & 25 & 0.56 \\
\hline Fluorene & 900 & 5 & 2.2 \\
\hline Fluoranthene & 250 & 1 & 0 \\
\hline Biphenyl & 500 & 250 & $0.8^{C}$ \\
\hline Chrysene & 25 & 0 & \\
\hline Dibenzofuran & 750 & 0 & \\
\hline Rubrene & 25 & 10 & $0.1^{c}$ \\
\hline Perylene & 10 & 5 & $1.8^{c}$ \\
\hline 1,2-Benzofluorene & 100 & 50 & $4.2^{c}$ \\
\hline Anthanthrene & 100 & 50 & $0^{c}$ \\
\hline 1,2-Benzanthracene & 500 & 100 & 0.75 \\
\hline 1-4-Dibenzanthracene & 50 & 5 & $2.0^{c}$ \\
\hline 3,4-Benzopyrene & 75 & 15 & 1.1 \\
\hline $2,3,6,7$-Dibenzanthracene & 20 & 10 & 0.2 \\
\hline
\end{tabular}




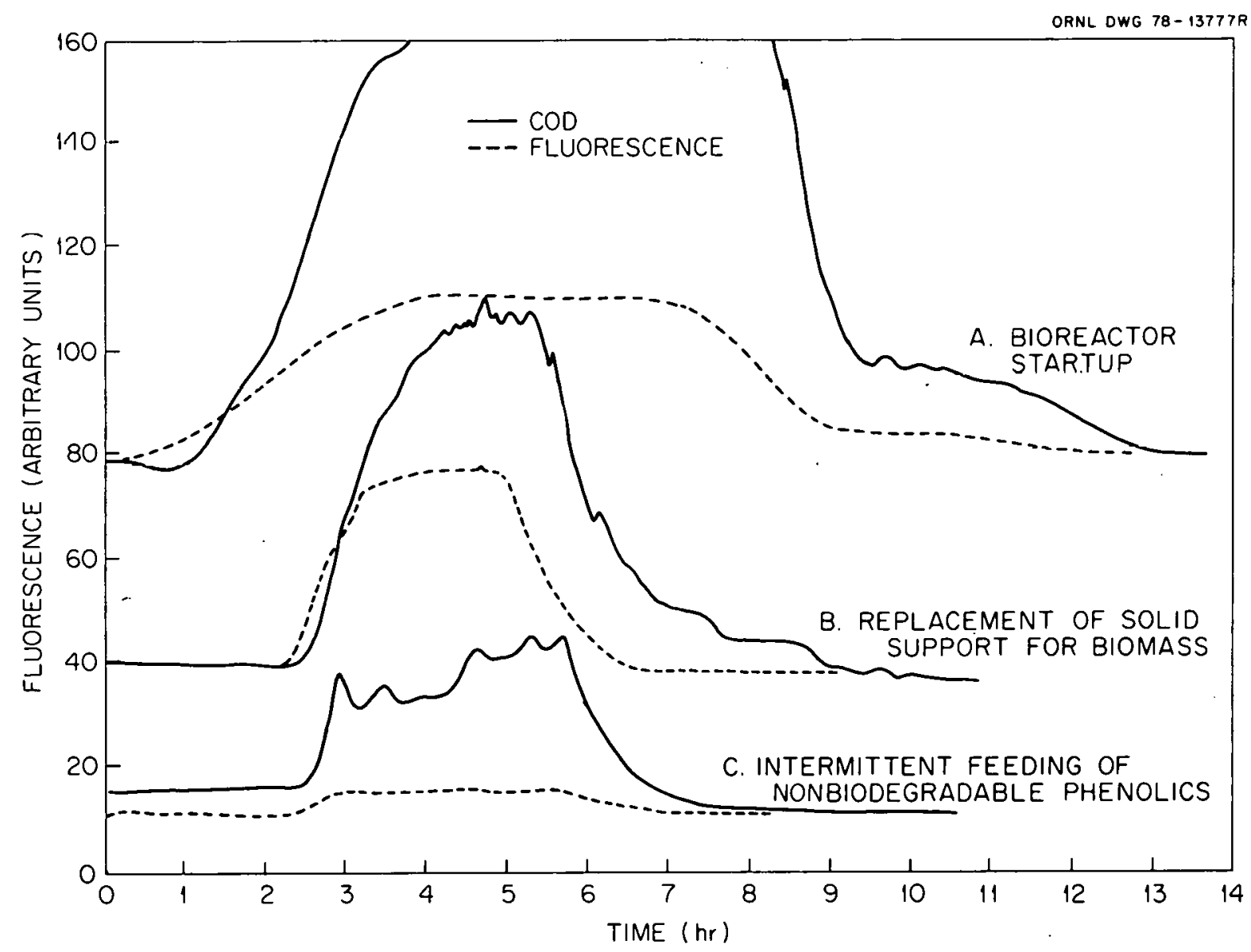

Figure 11. Examples of aquatic environmental monitor recorder traces.

recovers and starts producing clean effluent. Trace $C$ shows the effect of augmenting the wastewater with nonbiodegradable phenolic compounds. The AEM detects their presence as COD in the effluent.

\subsection{Effluent from Municipal Activated Sludge Treatment Plant}

The AEM was used to determine the level of pollution of secondary sewage efflucnt from the Oak Ridye East Waste Treatment riant before and after chlorination. The effluent contained $9-\mu \mathrm{g} / \mathrm{mI}$ COD both before and after chlorination, but the native fluorescence was reduced $\sim 20 \%$ by chlorination (Table 4). 
Table 4. Organic contamination in the Oak Ridge East Waste Treatment Plant secondary effluent

\begin{tabular}{lcc}
\hline & $\begin{array}{c}\text { COD } \\
(\mathrm{mg} / \ell)\end{array}$ & $\begin{array}{c}\text { Fluorescence } \\
(\mathrm{mV})^{\alpha}\end{array}$ \\
\hline Before chlorination & 9 & 38 \\
After chlorination & 9 & 30 \\
\hline
\end{tabular}

$a_{1 \mathrm{mV}}$ corresponds to the fluorescence of $1 \times 10^{-5} \underline{\mathrm{M}} \mathrm{Ce}(\mathrm{III})$.

\subsection{Other Applications}

Two other applications of components of the AEM briefly investigated were the use of the flow fluorumeter as a monitor for PAHs in drinking water, and the use of the CCOD for routine analysis of COD before and after an experimental wastewater treatment.

Because of the carcinogenicity of some PAHs and the1r rather ubiquitous nature, a need was perceived for an inexpensive, continuous monitor for PAHs in drinking water. Consequently, the PAH monitor portion of the AEM was evaluated for this purpose.

The ORNL flow fluorometer $\left(\lambda_{\text {ex }}-254 \mathrm{~nm} ; \lambda_{\text {em }}-320 \mathrm{~nm}\right)$ was adjusted to the most sensitive settings, which had a noise level of $<1 \%$ of full scale with a sample flow of $2 \mathrm{l} / \mathrm{h}$. Under these conditions, instrument drift was less than $1 \%$ per day, and $250 \mu \mathrm{g} / \ell$ of phenanthrene could be detected at a signal-to-noise ratio of 2 . Monitoring of ORNL process water gave no indication of PAH contamination.

In response to a recognized need for major near-term decreases in the energy intensiveness of conventional technologies for treating wastewaters, ORNL has been engaged in the development and demonstration of a wastewater treatment technology based on an anaerobic, fixed-film bioreactor (ANFLOW). ${ }^{6}$ As part of the supporting research for this technology, ten bench-scale bioreactors were operated under identical conditions except for hydraulic residence times, which were 2,4 , and $12 \mathrm{~h}$. Feed and effluent samples were analyzed for COD on a routine basis using the CCOD portion of the AEM. Ranges of COD removal efficiencies for each of the residence times are shown in Fig. 12. 


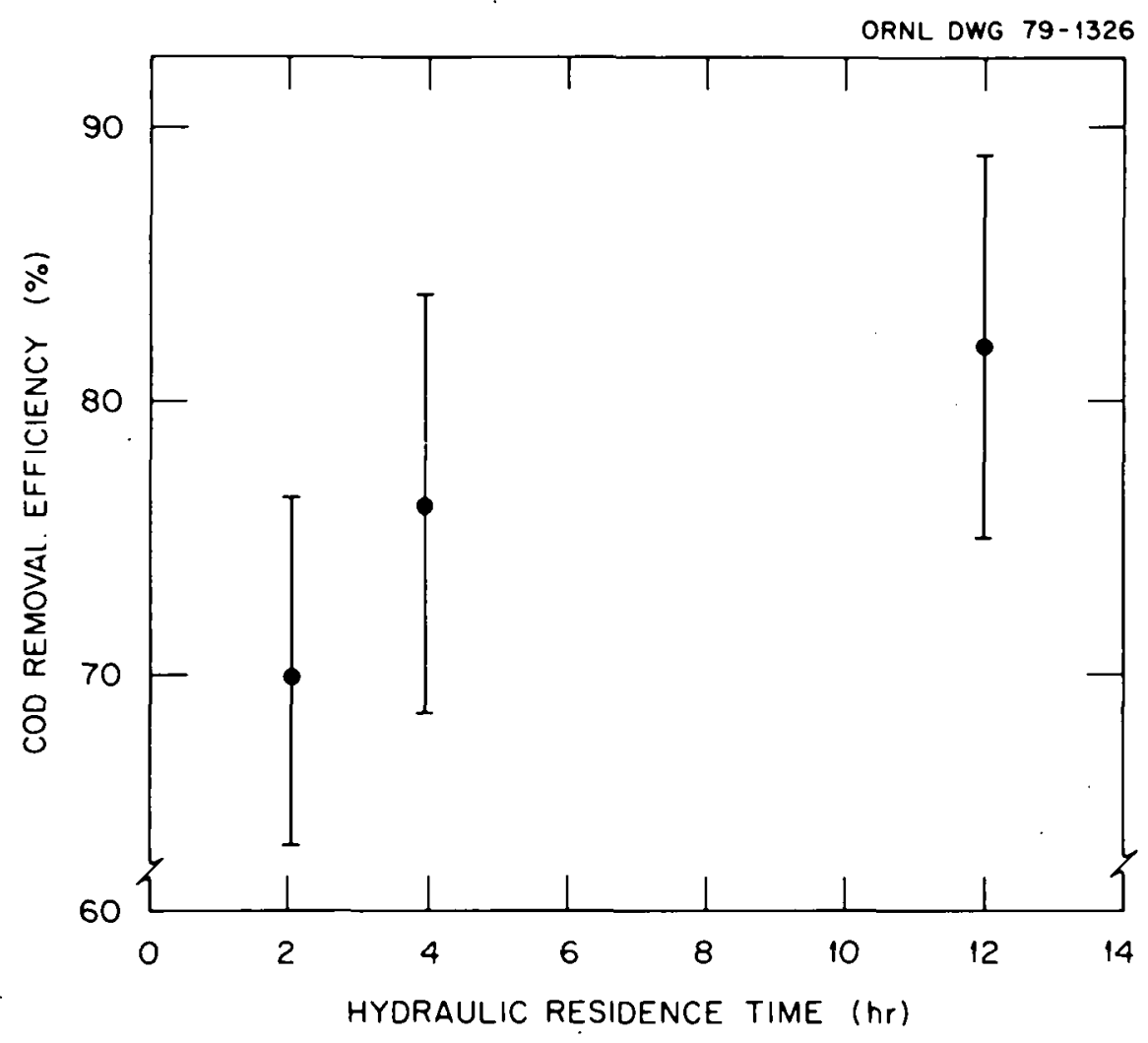

Figure 12. Measured chemical oxygen demand removal efficiency of anaerobic bioreactor as a function of residence times.

\section{SUMMARY}

An instrument capable of continuous monitoring of aqueous streams for contamination from coal conversion processes has been assembled and tested. The monitor was shown to be capable of measuring contamination by phenolics in the range of 1 to $10 \mathrm{mg} / \ell$ and $\mathrm{PAH}$ contamination at concentrations below $100 \mu \mathrm{g} / \mathrm{l}$. These concentrations are about the levels of the existing or anticipated discharge regulations. Tests with several actual effluents show the versatility and utility of the instrument.

\section{REFERENCES}

1. W. A. Armstrong, D. W. Grant, and W. F. Humphreys, Anal. Chem. $\underline{35}$, 1300 (1963):

2. W. W. Pitt, Jr., S. Katz, and L. H. Thacker, "A Rapid, Sensitive Method for the Determination of the Chemical oxygen Nemand of Polluted Waters," AIChE Symp. Ser. 129, 69 (1975). 
3. L. H. Thacker, "Improved Miniature Flow Fluorometer for Liquid Chromatography," J. Chromatogr. 136, 213 (1977).

4. J. A. Klein and R. E. Barker, Assessment of Environmenta1 Control Technology for Coal Conversion Aqueous Wastes, ORNL/TM-6263 (July 1978).

5. D. D. Lee, C. D. Scott, and C. W. Hancher, "Fluidized-bed Bioreactor for Coal Conversion Effluents," J. Water Pollut. Control Fed. 51(5), 974 (1979).

6. R. K. Genung, D. L. Million, C. W. Hancher, and W. W. Pitt, Jr., "Piloc-Pldul Demunstration of an Anaerobic Fixed-Fi7m Rinreactor for Wastewater Treatment," Biotechnol. Bioeng. Symp. 8, 329 (1978). 
ORNL/TM-6118

INTFRNAL DISTRIBUTION

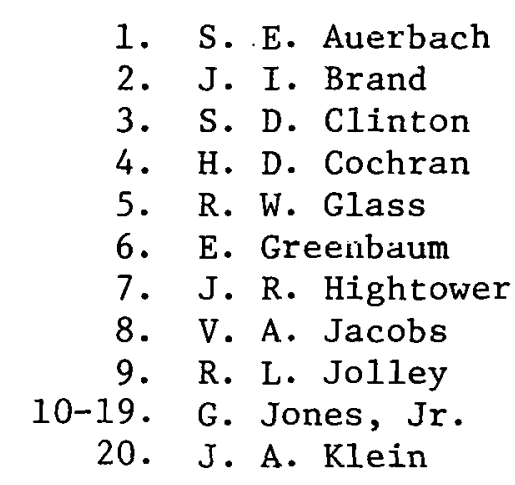

1. S. E. Auerbach

J. I. Brand

3. S. D. Clinton

4. H. D. Cochran

5. R. W. Glass

6. E. Greenbaum

7. J. R. Hightower

8. V. A. Jacobs

9. R. L. Jolley

20. J. A. Klein
21-30. W. W. Pitt, Jr.
31. D. D. Schuresko
32. W. D. Shults
33. S. E. Shumate II
34. L. H. Thacker
35-36. Laboratory Records
37. Laboratory Records - RC
38. Central Research Library
39. Y-12 Technical Library
Document Reference Section
40. ORNL Patent Office
41-100. TC/U office

EXTERNAL DISTRIBUTION

101. C. E. Carter, Office of Health and Environmental Research, Division of Health Effects Research, DOE, Washington, D.C. 20545.

102. C. W. Edington, Office of Health and Environmental Research, DOE, Washington, D.C. 20545.

103. R. W. Wood, Office of Health and Environmental Research, Division of Pollutant Characterization and Safety Research, DOE, Washington, D.C. 20545.

104. Office of Assistant Manager, Energy Research and Development, DOE-ORח, P. O. BOIr E; Oak Rilye, TIN $3783 U$.

1U5-131. Technical Information Center, Oak Ridge, TN 37830. 